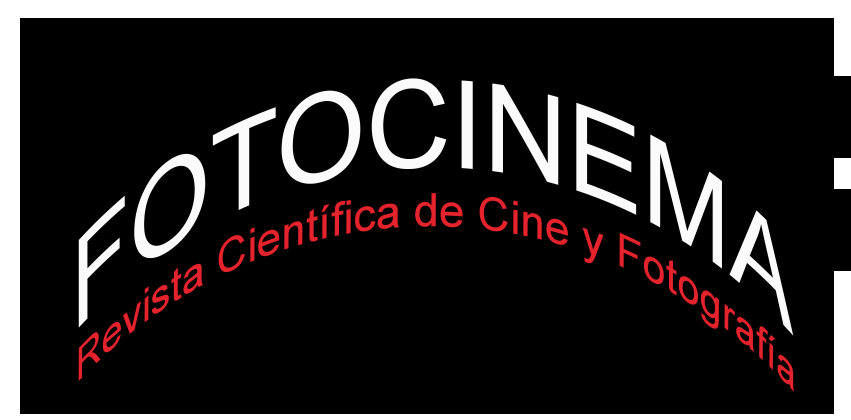

\title{
EL PAISAJISMO OBSERVACIONAL DE JAMES BENNING: LA REPRESENTACIÓN DE LOS ANGELES EN LOS (2000)
}

\section{JAMES BENNING'S OBSERVATIONAL LANDSCAPING. THE REPRESENTATION OF LOS ANGELES IN LOS (2000)}

\section{Resumen:}

El James Benning es uno de los grandes cineastas del paisaje norteamericano. Sus películas se sitúan en la intersección entre el cine documental y el experimental, y suelen contrastar el medio natural con el medio modificado, el campo con la ciudad y el pasado con el presente, siempre a medio camino entre el esplendor de la modernidad y la decadencia post-industrial. Su puesta en escena se basa en la observación atenta del territorio, aunque a veces también incluye elementos performativos.

La Trilogia de California (1999-2001), en concreto, propone una cartografía crítica del paisaje californiano a través de sus tres partes -El Valley Centro (1999), Los (2000) y Sogobi (2001)- dedicadas respectivamente a los paisajes rurales, urbanos y naturales. Cada una de estas películas consta de treinta y cinco planos fijos de dos minutos y medio cada uno, un dispositivo minimalista capaz de transmitir mucha información sobre el paisaje, la historia y la sociedad norteamericana, así como sobre la propia vida del cineasta.

El objetivo de este artículo es, por lo tanto, analizar la representación que Benning ofrece de Los Angeles en Los para comprender las características principales de su estilo, identificado como paisajismo observacional, y las implicaciones socio-históricas de su discurso.
Iván Villarmea Álvarez

Universidad de Zaragoza, España ivillarmea@gmail.com

\section{Abstract:}

James Benning is one of the great landscape filmmakers in American cinema. His works are located at the meeting point between documentary and experimental film, and they usually compare the natural and built environment, the country and the city, and the past and the present, always halfway between modernity's heyday and post-industrial decay. His mise-en-scène is based on the attentive observation of the territory, but sometimes it also includes performative elements.

The California Trilogy (1999-2001), in particular, offers a critical mapping of the California landscape throughout its three parts -El Valley Centro (1999), Los (2000) and Sogobi (2001) - which are respectively devoted to rural, urban and natural landscapes. Each of these works consists of thirty-five two-and-one-halfminute fixed shots, a minimalist device able to convey much information on American landscape, history and society, as well as on the filmmaker's personal life.

The aim of this paper is therefore to analyse Benning's representation of Los Angeles in Los in order to understand the main features of his style -which has been identified as observational landscapingand the socio-historical implications of his discourse.

Palabras clave:

Paisajismo; cine documental; cine experimental; James Benning; trilogia de California; Los Angeles.

Keywords:

Landscaping; Documentary Film; Experimental Film; James Benning; California Trilogy; Los Angeles. 


\section{Introducción: paisajismo}

El término 'paisajismo' suele referirse a cualquier actividad que modifique las características visibles del territorio, pero también identifica el género pictórico, fotográfico o cinematográfico que se centra en su representación. En concreto, el paisajismo cinematográfico, en su modalidad documental, es una tradición estética que confronta a cineastas y espectadores con un entorno natural o humanizado mediante la observación atenta y normalmente inmóvil de los elementos profílmicos. Su puesta en escena se organiza en función de tres elecciones básicas: en primer lugar, encontrar una posición de cámara adecuada para abarcar el entorno que se quiere mostrar; en segundo lugar, decidir la movilidad de la cámara, que se puede mantener inmóvil en un plano fijo, girar sobre sí misma en una panorámica, o desplazarse sobre un eje en un travelling; y en tercer lugar, establecer la duración exacta del plano en el montaje final.

Aquellas películas que basan su propuesta en este dispositivo suelen preferir los planos de larga duración porque estimulan el inconsciente óptico del espectador: al mantener la misma imagen durante más tiempo del necesario según lo establecido por las convenciones narrativas del relato audiovisual mainstream, los cineastas invitan al público a que se fijen en detalles y aspectos que en una primera visión no han percibido aunque siempre hayan estado a la vista. Además, la duración del plano resulta clave para diferenciar el paisajismo cinematográfico de su equivalente fotográfico, ya que las posibilidades comunicativas de la imagen en movimiento pueden cambiar, ampliar o contrastar el mensaje inicial de un encuadre congelado. La pregunta obligada en estos casos es 'c̉por qué y para qué esta imagen dura tanto tiempo?', y su respuesta, cuando este dispositivo está bien utilizado, es que los planos largos le dan a estos paisajes un nuevo significado, o al menos un significado diferente al habitual, que permite interpretar su representación en términos políticos, económicos, sociales, culturales, urbanísticos, ecológicos o directamente ideológicos.

El paisajismo se interesa, en líneas generales, por la forma del espacio, su evolución histórica, su apariencia actual y, sobre todo, por su percepción 
visual, dado que cualquier espacio cinematográfico es siempre percibido de forma doble: primero por el cineasta y después por el público. Por ejemplo, el paisajismo documental estadounidense de la primera década del siglo XXI plantea, según Elena Oroz e Iván G. Ambruñeiras, “una especie de geografía crítica que trabaja sobre el significado político y cultural de los lugares (y nolugares) para rastrear en ellos tanto las huellas de su pasado como su función actual” (Oroz \& Ambruñeiras, 2010, p. 119). En estas películas, los signos del paso del tiempo se interpretan a modo de presencias, ausencias o incluso como la superposición de ambas, dando lugar a un palimpsesto en el que la acumulación de significados socio-históricos y experiencias subjetivas establece un vínculo entre los relatos colectivos y la memoria personal. Esta condición de depósito de acontecimientos y emociones hace que el paisaje desempeñe una "función social” como explicó el urbanista estadounidense Kevin Lynch en su obra La imagen de la ciudad:

El medio ambiente con sus denominaciones, familiar para todos, proporciona material para recuerdos y símbolos comunes que ligan al grupo y le permiten comunicarse entre sus miembros. El paisaje actúa como un vasto sistema mnemotécnico para la retención de la historia y los ideales colectivos (Lynch, 2008, p. 153).

Lynch estudiaba la percepción del espacio urbano por parte de sus habitantes, es decir, su cartografía cognitiva, porque consideraba que comprender la relación entre el ser humano y su entorno era una herramienta imprescindible para intentar mejorar dicho entorno. Según él, las actuaciones de reforma urbana no tenían que cambiar "la forma física misma sino la calidad de una imagen en la mente”, ya que la cartografía cognitiva se organiza mediante imágenes ambientales que no son única y exclusivamente el resultado de las características exteriores de un lugar, sino también el producto de la percepción de un observador determinado (Lynch, 2008, pp. 143 \& 194). Por lo tanto, si el paisaje puede ser condensado en una imagen mental, su registro cinematográfico podría ser una encarnación aproximada de dicha imagen, o más exactamente, de la imagen ambiental del cineasta. Este registro incluiría también los significados socio-históricos y las experiencias subjetivas asociadas al paisaje, de manera que su análisis 
posterior haría posible recuperar distintas cartografías cognitivas del pasado para explicar la relación de individuos y comunidades con su entorno a lo largo del tiempo.

\section{Marco teórico y metodología: el cine como tecnología de lugar}

La relación entre el cine y el paisaje ha sido un tema recurrente en los estudios cinematográficos de las últimas décadas, sobre todo en el caso del paisaje urbano (ver Althabe \& Comolli, 1994; Niney, 1994; Barrios, 1997; Clarke, 1997; Shield \& Fitzmaurice, 2001, 2003; Barber, 2002; Krause \& Petro, 2003; Mazierska \& Rascaroli, 2003; Everett \& Goodbody, 2005, Jousse \& Paquot, 2005; AlSayyad, 2006; Mennell, 2008; Webber \& Wilson, 2008; Harper \& Rayner, 2010; Koeck \& Roberts, 2010; Rodríguez Ortega 2012). Hasta hace pocos años, no obstante, el paisaje se interpretaba como un marco contextual o atmosférico en el que se situaba el relato de la película, pero no como el origen o la manifestación de ese relato. Han tenido que ser los estudios urbanos los que han comenzado a abordar el cine como un medio capaz de producir espacialidad -en el sentido que Henri Lefebvre le daba a este término (Lefebvre, 1974)- a través del conjunto de sus distintas tareas creativas: el rodaje en exteriores, la puesta en escena, el encuadre, la iluminación y el montaje (Brunsdon, 2010, p. 94). El historiador cultural estadounidense Edward Dimendberg, por ejemplo, escribió un libro muy influyente titulado Film Noir and the Spaces of Modernity en el que analizaba la evolución del urbanismo americano desde 1939 hasta 1959 en paralelo con el desarrollo del cine negro (Dimendberg, 2004). Esta obra, junto a otras, inspiró un nuevo método de analizar películas que Richard Koeck y Les Roberts han resumido del siguiente modo: "un método que consiste en entender el cine no sólo como un texto dependiente de una serie de convenciones genéricas, sino como un mapa de discursos socio-culturales, políticos, económicos y, por supuesto, arquitectónicos” (Koeck \& Roberts, 2010, p. 10) ${ }^{1}$.

\footnotetext{
${ }^{1}$ Esta, y el resto de las traducciones de los textos en inglés, son mías.
} 
La metáfora del mapa ha llevado a Teresa Castro a comparar "la exploración del cine del espacio urbano" con "una forma de cartografía visual" (Castro, 2010, p. 144). Según ella, "la asociación entre el ojo y el instrumento que distingue a la observación cartográfica del espacio no es muy diferente de la que determina la cuidadosa codificación a escala del mundo que ha establecido el cine” (Castro, 2010, p. 145). En concreto, a la hora de cartografiar el paisaje urbano, esta autora distingue tres estrategias formales diferentes:

La primera está vinculada a una cierta fascinación topográfica, si no directamente a una verdadera topofilia, en su sentido de 'amor al lugar'. Desde esta perspectiva, la noción de cartografía se refiere menos a un instrumento disciplinario de dominación visual que a un medio de auto-descubrimiento. (...) Esta fascinación topográfica va de la mano de un segundo procedimiento formal que alude a la aparente motivación descriptiva de las imágenes en cuestión, evidenciadas por determinados movimientos de cámara como las panorámicas o los travellings. En este segundo caso, la noción evocada de cartografía es sin duda más convencional, puesto que la cartografía, entendida como una tecnología cultural, suele funcionar como una forma de catalogar las principales características de la superficie terrestre. (...) Por último, la tercera estrategia formal sería la exploración del territorio, ya sea caminando -la práctica espacial por excelencia- o observándolo desde lo alto (Castro, 2010, p. 145).

Cada una de estas tres estrategias es, antes que nada, "un acto de producción del discurso", como ha dicho Colin McArthur, porque en última instancia expresa la posición del cineasta con respecto al espacio filmado (McArthur, 1997, p. 40). Por lo tanto, las imágenes resultantes pueden tener un valor histórico, identitario o simplemente expresivo en función de la propia agenda del cineasta. Puesto que el significado de un paisaje suele cambiar de una película a otra (y de un observador a otro), el significado de un dispositivo cinematográfico siempre dependerá del contexto en el que se utiliza y, sobre todo, del propósito al que sirve.

Teniendo en cuenta este marco teórico, la metodología que se empleará en este artículo será el análisis cualitativo de una determinada tradición estética, el paisajismo observacional, y de una película en concreto, Los (James 
Benning, 2000). Las principales herramientas hermenéuticas empleadas para desarrollar este análisis serán distintos conceptos de origen artístico, literario, urbanístico o sociológico que permitirán una decodificación activa de las imágenes la película más allá de su contexto original. Al tratarse de un análisis espacial, la obra objeto de estudio será poco menos que cartografiada sobre el territorio, buscando sus posiciones de cámara originales siempre que esto sea posible, para así descubrir tanto el patrón geográfico que revelan sus imágenes como el significado e implicaciones que emanan de dicha representación.

\section{Tipos de paisajismo: observacional, psicogeográfico y autobiográfico}

Según el grado de subjetividad es posible distinguir tres tipos de paisajismo: observacional, psicogeográfico y autobiográfico. El más objetivo sería el primero, el paisajismo observacional, que se caracteriza por una puesta en escena minimalista limitada a registrar la imagen y el sonido ambiente del paisaje. El cineasta que mejor ha utilizado este dispositivo es sin duda James Benning, el director de la Trilogía de California, un tríptico formado por $E l$ Valley Centro, Los y Sogobi (1999, 2000, 2001) que establece una dialéctica circular entre el medio rural, el espacio urbano y la naturaleza salvaje.

El segundo tipo de paisajismo conlleva un mayor grado de subjetividad por parte del cineasta, que se dedica a contrastar la apariencia contemporánea del paisaje filmado con sus encarnaciones anteriores, es decir, con aquellos acontecimientos que ocurrieron en ese mismo lugar años atrás (o incluso siglos) y con los edificios o estructuras que lo han ocupado en el pasado. Este dispositivo podría llamarse paisajismo psicogeográfico, puesto que hace referencia a obras que retratan el paisaje como emplazamiento histórico y también como espacio vivido, prestando especial atención a los efectos emocionales del territorio en el sujeto, que puede ser tanto el espectador como el cineasta. Algunos ejemplos de esta modalidad serían L.A.X. (Fabrice Ziolkowski, 1980), Thames Film (William Raban, 1986), Die leere Mitte (Hito Steyerl, 1998), California Company Town (Lee Anne 
Schmitt, 2008), Ruínas (Manuel Mozos, 2009) y muy especialmente la Trilogía de Robinson, formada por London, Robinson in Space y Robinson in Ruins (Patrick Keiller, 1994, 1997, 2010).

Por último, el tercer tipo de paisajismo sería el más subjetivo, porque desarrolla una lectura personal del territorio basada en las propias experiencias del cineasta. En principio, no habría demasiadas diferencias entre esta forma de filmar el espacio y las dos anteriores, pero esta vez las imágenes suelen venir acompañadas por un comentario en primera persona que explicita el vínculo entre cineasta y paisaje. Por este motivo, dado que este comentario suele tener un claro componente autobiográfico, este dispositivo podría identificarse como paisajismo autobiográfico. Así, en películas como News from Home (Chantal Akerman, 1977) o Lost Book Found (Jem Cohen, 1996), el espacio representado es siempre un espacio vivido.

\subsection{Paisajismo observacional}

El grado cero de puesta en escena consiste en establecer la posición de la cámara y la duración del plano, nada más. Aquellos trabajos cuyas principales decisiones estéticas se limitan a estas dos variables suelen describirse como primitivistas, dado que los pioneros del cine mudo -los cineastas primitivos- fueron los primeros en plantearse estas cuestiones. Noël Burch teorizó su estética en el Modo de representación primitivo, un concepto que agrupa una serie de estilos propios del cine mudo caracterizados por "la autarquía del encuadre (...), la posición horizontal y frontal de la cámara, la utilización de planos de larga duración y la “centrifugalidad”' (Burch, 1990, p. 188). Para Burch, estos elementos identificaban el ideal del cine puro, una percepción tan extendida que desde hace décadas todos los movimientos cinematográficos y dispositivos formales que intentan recuperar la esencia del cine vuelven una y otra vez a estas convenciones. El paisajismo observacional no es una excepción a esta regla, pero sus principales influencias son en realidad un poco más recientes: el cine estructural y la estética de la desaparición. 
El cine estructural apareció en Estados Unidos en los años sesenta y se desarrolló posteriormente en el Reino Unido. Sus principales representantes fueron los cineastas estadounidenses Michael Snow, Hollis Frampton, Paul Sharits, Joyce Wieland, Tony Conrad, George Landow y Ernie Gehr, así como los realizadores y teóricos británicos Peter Gidal y Malcolm Le Grice. Todos ellos estaban especialmente preocupados por cuestiones formales, hasta el punto de considerar que el contenido de sus películas debía ser "mínimo y subsidiario a la forma”, según la afirmación de P. Adams Sitney (Sitney, 2000, p. 327). Para este crítico, las cuatro principales características del cine estructural eran "la posición fija de la cámara (fija desde el punto de vista del espectador), el efecto de parpadeo, el montaje en bucle y la refilmación de la propia pantalla”, aunque ninguna película incluía todas estas características juntas (Sitney, 2000, p. 327). La lógica temporal de estos trabajos trataba de alcanzar la estética del tiempo real, en la que el tiempo en pantalla tenía que ser igual al tiempo del rodaje, una elección formal que más tarde influenciaría los trabajos de James Benning.

La estética de la desaparición, a su vez, comienza con las películas de principios de los años sesenta de Michelangelo Antonioni, sobre todo L'Avventura (1960), en la que un personaje sale del encuadre para no volver a entrar en él jamás, y L'Eclisse (1962), en la que es la propia historia la que se disuelve en el paisaje urbano. La última secuencia de esta última muestra varios lugares visitados previamente por su pareja protagonista, lugares en donde esos personajes se tendrían que volver a encontrar, aunque finalmente ninguno de los dos aparece. Su ausencia está enfatizada por una serie de objetos inanimados - una persiana metálica, una manguera, un paso de cebra, una casa en construcción o un pequeño trozo de madera flotando en un bidón de agua- que representan el eclipse de sus sentimientos. Esta forma de filmar establece, según Domènec Font, "una contigüidad entre ambientes y personajes que se explicita mediante una triple ecuación entre el espacio psíquico interior, el espacio arquitectónico y el espacio del encuadre” (Font, 2002, p. 311). Por lo tanto, en L'Eclisse, una casa en construcción en las afueras de Roma simboliza tanto el nuevo paisaje suburbano de la época como el vacío emocional de la burguesía italiana. 
El estilo de Antonioni ha influenciado a un buen número de cineastas, desde Wim Wenders a Apitchapong Weerasethakul pasando por Théo Angelopoulos, Béla Tarr, Tsai Ming-liang o Nuri Bilge Ceylan, entre muchos otros. Weerasethakul llegó incluso a reescribir la secuencia final de L'Eclisse en Syndromes and a Century (2006), como ya habían hecho Richard Linklater y Lee Chang-dong en Before Sunrise (1995) y Poetry (2010) respectivamente. Estos dos últimos cineastas querían mostrar la ausencia o la desaparición de sus personajes, pero Weerasethakul citaba a Antonioni para expresar un vacío ontológico que ha sido explorado recientemente por el llamado slow cinema, un estilo descrito por Jonathan Romney como "un cine que ralentiza los acontecimientos para primar la atmósfera, la evocación y un sentido más intenso de la temporalidad” (Rommey, 2010, p. 43). En obras como Sátántangó (Béla Tarr, 1994), La libertad (Lisandro Alonso, 2001), Gerry (Gus Van Sant, 2002), Goodbye Dragon Inn (Tsai Ming-liang, 2003) o El cant dels ocells (Albert Serra, 2008), la estética de la desaparición ha evolucionado en una estética del vacío en la que ya no hay relato, sino rastros de relato. La estructura narrativa ha sido despojada de lo que antes entendíamos como principio y desenlace para centrarse tan sólo en el nudo, del que debemos deducir todo. En estas circunstancias, el paisaje suele jugar un papel clave como personaje, símbolo o motivo estético, hasta el punto de que muchas de estas películas, a pesar de ser ficciones, bordean el paisajismo documental.

La capacidad del slow cinema -y, por extensión, del paisajismo observacional- para capturar el tiempo presente ha sido cuestionada por algunos críticos que consideran estas obras un poco desfasadas. Por ejemplo, Horacio Muñoz Fernández ha afirmado que "una buena parte del cine paisajístico contemplativo u observacional es estéticamente romántico, tópicamente antimoderno y teóricamente erróneo” (Muñoz Fernández, 2013). Anteriormente, Antonio Weinrichter ya se había preguntado qué sentido tiene representar nuestra experiencia en un mundo sobresaturado de imágenes al sustituir "el paradigma del zapping por la panorámica o el encuadre fijo de ritmo geológico” (Weinrichter, 2007, p. 72). La lentitud, no obstante, suele tener una agenda ideológica clara: contrarrestar la lógica del 
espectáculo, arriesgándose si hace falta a inducir a buena parte de los espectadores al sueño. Para todos aquellos capaces de mantenerse despiertos, la puesta en escena del paisajismo observacional puede documentar un lugar, transmitir su experiencia subjetiva o llamar la atención sobre los usos y abusos del territorio en el que está situado.

En estas películas, el encuadre funciona siempre como el mediador entre el paisaje, el cineasta y el público: su composición determina la experiencia que el espectador tiene del paisaje al tiempo que evoca la experiencia del cineasta durante el rodaje. De esta manera, el paisajismo observacional ofrece una mezcla de objetividad explícita -porque el público mira directamente el paisaje- y subjetividad implícita - porque el público se sitúa en la misma posición que el cineasta. Esta doble decodificación del cine paisajista explica porqué muchos cineastas varones, blancos y heterosexuales comenzaron a buscarse a sí mismos en el paisaje tras el giro subjetivo del documental, según lo expuesto por David E. James:

[La auto-exploración y auto-producción iniciada por los colectivos multiculturales] precipitó una crisis que fue específicamente aguda para un grupo determinado de cineastas: los varones blancos heterosexuales. Excluidos por definición de los cines de las minorías y peligrosamente asociados con el hiperracionalismo putativo del cine estructural, estos cineastas no podían crear un cine contrario al mainstream a partir de la psique de un protagonista individual ni de su proyección social en forma de movimiento político. Dado que la historia de los hombres blancos heterosexuales parece haber sido contada una y otra vez en el mainstream -de hecho, hay quien opina que es la única historia que la cultura del capitalismo patriarcal ha permitido contareste tipo de creadores ya no dispone de ninguna contra-historia socialmente viable que enunciar. Carentes por lo tanto de un relato o del recurso a una subjetividad funcional, los hombres blancos heterosexuales han cambiado su perspectiva desde el interior al exterior y desde el tiempo al espacio, de modo que si hay algún lugar en el que puedan encontrarse a sí mismos es en la geografía y en el cine paisajístico (James, 2005, p. 413). 
James Benning, según Nils Plath, sería uno de esos cineastas que se han redescubierto a sí mismos como "un ser perceptivo en el espacio" (Plath, 2007, p. 201). En los años setenta, sus principales referentes estéticos eran Andy Warhol, Michael Snow y Hollis Frampton (Benning en Yáñez Murillo, 2009, p. 81; Bradshaw, 2013, p. 46), pero su obra evolucionó posteriormente hacia una puesta en paisaje muy influenciada por el Land Art. ${ }^{2} \mathrm{Al}$ igual que buena parte del cine paisajista, toda su filmografía se basa en la elección del encuadre adecuado, dentro del que introduce "elementos de intriga narrativa a través de acciones marginales y especialmente de la superposición de capas en la banda de sonido" (Martin, 2010, p. 198). Los planos resultantes establecen un juego constante con el espacio fuera de campo mientras muestran una iconografía recurrente compuesta por "grupos de vacas, trenes atravesando el encuadre, chimeneas lanzando humo, campos recién arados, vallas publicitarias, disparos, pozos de petróleo [y] todo tipo de carreteras" (Ault, 2007, p. 106). Allá en donde haya estado, Benning siempre se las arregla muy bien para transmitir el sentido del lugar a través de la duración del plano: según él, "un lugar existe siempre en función del tiempo, por lo que uno tiene que sentarse a mirar y escuchar durante un periodo de tiempo para captar el sentido de ese lugar y decidir cómo representarlo” (Ault, 2007, pp. 91-92). La duración es, por tanto, el factor clave "para dar tiempo [al espectador] a pensar una imagen mientras la está viendo, [puesto que] la forma en que pensamos una imagen cambia en el curso de su duración” (Benning en Ault, 2007, p. 88). De ahí que, sabiendo mirar y escuchar, las películas de Benning pueden ser decodificadas tanto en términos históricos como personales, como ha sugerido Julie Ault:

La obra de Benning es tanto un registro de su conciencia en el tiempo y el espacio, y por lo tanto de su memoria y de como él incorpora el tiempo y el espacio en su propio interior, como una reflexión sobre la sociedad, la industria, la raza, la historia, el paisaje, el Medio Oeste, el Oeste americano y América en su conjunto (Ault, 2007, pp. 111-112).

\footnotetext{
${ }^{2}$ Benning ha realizado incluso una película sobre la Spiral Jetty de Robert Smithson, una inmensa escultura en espiral construida con basalto negro que se encuentra en la orilla oriental del Gran Lago Salado de Utah. Este trabajo se titula Casting a Glance (James Benning, 2007) y muestra los cambios en la obra de Smithson producidos por la erosión y el paso del tiempo.
} 
Esta polisemia tiene que ver con la naturaleza abierta del mejor cine paisajístico, que puede ser tan aburrido o tan significativo como el público quiera. En el caso de Benning, su hábito de filmar frecuentemente sus lugares de memoria crea una geografía cinemática provista de múltiples significados: así, por ejemplo, cuando en 1988 el cineasta se mudó a Val Verde, California, para enseñar en el California Institute for the Arts, su interés geográfico se fue desplazando gradualmente de los paisajes del Medio Oeste a los del Suroeste. La primera película de este nuevo periodo fue North on Evers (1991), una road movie que registra el itinerario de dos viajes en motocicleta desde Val Verde a New York y vuelta a Val Verde con una parada en Milwaukee. Esos dos viajes transcurrieron en parte por el estado de Utah, al que Benning dedicaría justo después su primer western, Deseret (1995), y parte de Four Corners (1997), una película que exploraba la cuádruple frontera entre Utah, Colorado, New Mexico y Arizona. Un año después, este desplazamiento hacia el oeste se completaría con UTOPIA (1998), en donde el cineasta filmó por primera vez los paisajes fronterizos del sur de California y el norte de Sonora. Su siguiente paso sería ya cartografiar los distintos tipos de paisaje californiano en la monumental Trilogía de California.

\section{La Trilogía de California: cartografía de un paisaje torturado}

Los vínculos geográficos entre las distintas películas de Benning son, según él mismo ha explicado, resultado de la influencia que cada nueva obra recibe de su inmediata predecesora (MacDonald, 2006, p. 242; Ault, 2007, pp. 105-106). La Trilogía de California no es una excepción a esta regla: en primer lugar, El Valley Centro nació como una prolongación de UTOPIA al profundizar en la cuestión del uso productivo de la tierra; Los fue posteriormente concebida como su complemento urbano; y por último Sogobi mostró su contrario, la naturaleza salvaje, que también puede entenderse como origen del paisaje agrario. Esta transición del medio rural al medio urbano y vuelta al medio natural ha sido interpretada por James como "una dialéctica circular", en la que "la urbanidad industrial" -si 
empezamos con Los- "genera su antítesis, la naturaleza salvaje, y esta a su vez genera el paisaje agrario del Central Valley como una síntesis entre esos dos elementos -aunque este paisaje se parece cada vez más a la urbanidad expandida de Los Ángeles, de Los” (James, 2005, p. 423).

La unidad de la trilogía se da entonces a tres niveles a la vez: primero a nivel geográfico, ya que el conjunto de estas tres películas “aspira a representar el estado como un todo" (James, 2005, p. 426); después a nivel temático, porque el conjunto de la trilogía aborda las distintas formas de ocupación y explotación de la tierra; y por último a nivel formal, en la medida en que cada parte consiste en treinta y cinco planos fijos de dos minutos y medio de duración seguidos por una lista detallada de sus localizaciones del rodaje, en la que cada lugar está identificado por la acción que transcurre en él, por su ubicación y por su propietario. De este modo, según James, "la trilogía (...) [alude a] la división de clases que existe en el sistema social que estructura la geografía californiana" al mostrar "un reparto del trabajo controlado por los más ricos y las corporaciones” (James, 2005, pp. 427-428). En El Valley Centro, por ejemplo, los principales terratenientes parecen ser compañías transnacionales implicadas en el negocio del petróleo -Shell Oil Company, Chevron Corporation, Getty Oil, Texaco- o en el transporte de mercancías Southern Pacific Transportation Company, Union Pacific Railroad. Este paisaje está claramente "permeado por el capital y el trabajo", como ha señalado Claudia Slanar, puesto que todo lugar tiene un propietario y todo recurso natural se ha convertido en una mercancía, comenzando por el agua dulce (Slanar, 2007, p. 171). El interés de Benning por la agricultura de regadío y la política hidráulica californiana ya estaba presente en UTOPIA, pero la trilogía ha profundizado un poco más en la cuestión de sus beneficios económicos:

Las grandes corporaciones agrícolas se han aprovechado en el Central Valley de dos sistemas de irrigación construidos con dinero público: uno con fondos federales y otro con fondos estatales. Estas corporaciones no han financiado su construcción, pero los aprovechan plenamente: el 85\% del agua de California se utiliza para la agricultura, y tan sólo el 15\% para la industria y el consumo 
público. Además, por supuesto, Los Ángeles se ha expandido tanto gracias al robo del agua del Valle Owens.

Yo era muy consciente de esta política hidráulica cuando rodé El Valley Centro, y pensé, "bueno, cuando haga su complemento urbano tendré que hacer referencia a cómo estas políticas continúan vigentes de un sitio a otro". Así que Los comienza con agua fluyendo hacia LA a través del acueducto original que procede del Valle Owens; y después, en Sogobi, traté de mostrar de dónde venía toda esta agua (Benning en MacDonald, 2006, p. 250).
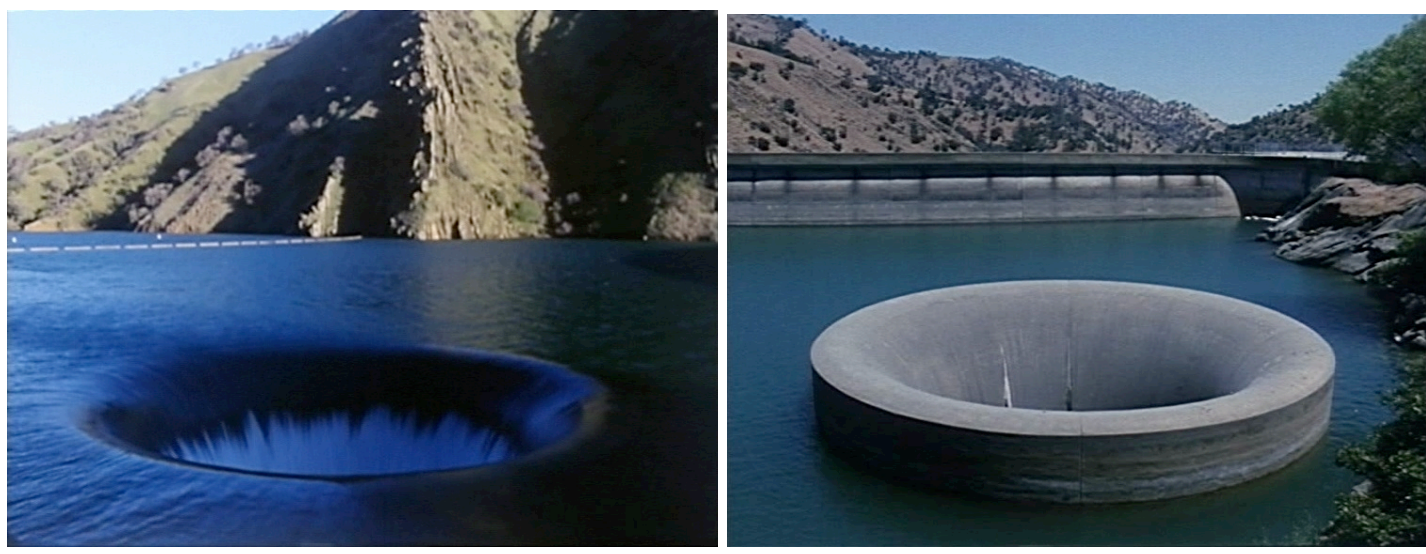

F. 1 y 2: El Valley Centro, primer plano (izquierda) y Sogobi, último plano (derecha). Aliviadero del Lago Berryesa

Los planos de infraestructuras hidráulicas sirven para establecer una continuidad visual y geográfica entre el final de una parte y el inicio de la siguiente: así, El Valley Centro comienza con el plano de un aliviadero circular en el Lago Berryessa [F 1] y termina con la imagen de una estación de bombeo en el acueducto de California; Los empieza precisamente con el acueducto de Los Ángeles y concluye en las playas de Malibú, frente al Océano Pacífico; y Sogobi, por último, parte de un acantilado rocoso en el California Sea Otter Refuge para retornar en su último plano al mismo aliviadero del Lago Berryessa que abría El Valley Centro [F 2]. Este cierre en bucle permite que la trilogía pueda ser reproducida de manera continua como una instalación audiovisual en la que el público podría entrar en cualquier momento de su proyección, una decisión formal determinada por la rigidez estructural de la trilogía que, en realidad, ayuda a articular su significado. 
Benning es muy consciente de que la percepción actual del paisaje californiano está totalmente mediada por sus múltiples representaciones, ya sea como reserva de territorio no humanizado o como un espacio de intereses en conflicto: la primera perspectiva considera que hay que conservar la naturaleza salvaje y protegerla de la erosión humana, mientras que la segunda se preocupa más por su potencial económico como fuente de materias primas, espacio urbanizable, reclamo turístico o incluso como localización cinematográfica. En opinión del cineasta, el paisaje californiano ha sido moldeado por la actividad humana desde hace siglos hasta el punto de haberse convertido en "un paisaje torturado" (Ault, 2007, p. 92). De hecho, vaya a donde vaya el cineasta a filmar, siempre se encuentra con el mismo proceso: el hombre trata de domesticar a la naturaleza, y la naturaleza responde infiltrándose en el espacio humano. Desde esta perspectiva, $E l$ Valley Centro muestra la transformación de la naturaleza salvaje en el paisaje rural; Los, la presencia de la naturaleza en las zonas urbanas; y Sogobi, la imposibilidad de encontrar una naturaleza inalterada.

La forma en la que el espacio ha sido producido en California, y muy especialmente en Los Ángeles, ha sido discutida y comentada por una larga tradición de geógrafos e historiadores entre los que destaca Mike Davis. En su obra Ciudades muertas. Ecología, catástrofe y revuelta, este autor ha resumido los principales problemas del modelo de desarrollo del Sun Belt hablando de Las Vegas como un clon perverso de Los Ángeles:

Las Vegas ha (1) abdicado a una ética responsable del agua; (2) ha fragmentado al gobierno local y lo ha subordinado a una planificación corporativa privada; (3) ha producido una insignificante cantidad de espacios públicos utilizables; (4) ha abjurado del uso de las «zonas de riesgo» para mitigar los desastres naturales y conservar el paisaje; (5) ha dispersado el uso de la tierra sobre un área enorme e innecesaria; (6) ha abrazado la consecuente dictadura del automóvil; y (7) ha tolerado la desigualdad social y particularmente la desigualdad racial (Davis, 2007, p. 109).

En este pasaje, Davis relaciona directamente la expansión de este modelo territorial con un empeoramiento en las condiciones de vida de la población más desfavorecida, una idea que había sido desarrollada previamente por 
Edward Soja en su obra Postmetrópolis. Estudios críticos sobre las ciudades y las regiones: "Los nuevos procesos de urbanización han producido la magnificación de las desigualdades económicas y extra-económicas (raciales, de género, étnicas) con consecuencias destructivas tanto en los entornos urbanos como en los naturales" (Soja, 2008, p. 564). En el caso concreto de Los Ángeles, la adaptación de la ciudad al nuevo paradigma económico de los años setenta y ochenta se produjo a costa de sacrificar la cohesión social y territorial de sus diferentes comunidades: así, mientras que el cierre de las fábricas del corredor que une South Central con Long Beach destruía miles de empleos entre la comunidad afroamericana, otras actividades basadas en el trabajo rápido y la mano de obra barata atrajeron a cientos de miles de trabajadores lationamericanos a la región. En estas circunstancias, el desequilibrio entre el nivel económico y la proporción demográfica de las principales comunidades de la ciudad llevó a Davis a parodiar su fuerza de trabajo en términos raciales: "una élite blanca de directivos profesionales, un sector de trabajadores públicos negros, una pequeña burguesía asiática y un proletariado de inmigrantes latinos" (Davis, 2007, p. 170).

La percepción del paisaje urbano por parte de estas cuatro comunidades no es obviamente la misma, dado que su distribución geográfica no es uniforme ni proporcional a su número. No obstante, una comunidad específica -los blancos acomodados del Westside- se ha aprovechado de su posición privilegiada desde un punto de vista socio-económico para controlar las representaciones espaciales de la ciudad e imponer al resto de comunidades su propia cartografía cognitiva: según ellos, Los Ángeles es una ciudad glamorosa de playas y palmeras habitada por una población mayoritariamente blanca, en lugar de ser una metrópolis multicultural con sus correspondientes ventajas y problemas. Para contrarrestar este espejismo, Benning retrata una ciudad completamente diferente en Los al centrarse en los cuatro tipos de paisaje que mejor definen el modelo territorial del sur de California: los paisajes expandidos (sprawlscapes), los paisajes intermedios (middle landscapes), los no-lugares (non-lieux) y los paisajes banales. 
El primero de estos conceptos, los paisajes expandidos, se refiere a aquellos paisajes producidos por "el crecimiento urbano que desborda los límites de la ciudad" (Ingersoll, 2006, p. 3). Desde los años cincuenta, muchas ciudades norteamericanas doblaron o triplicaron su extensión tradicional gracias a un proceso de suburbanización masivo, dando lugar a una sucesión no jerarquizada de casas unifamiliares, centros comerciales y espacios vacíos organizados en función de su acceso a las redes de transporte. Soja ha advertido que este proceso "podría estar más avanzado en el sur de California que en cualquier otro lugar de Estados Unidos", hasta el punto de se ha convertido, en realidad, en "una urbanización regional masiva” (Soja, 2008, p. 208). Las ciudades resultantes han sido elogiadas por críticos como Reyner Banham, que destacaba que "todas sus partes son iguales e igualmente accesibles desde cualquier otra parte” (Banham, 1971, p. 18, la traducción es mía), pero esta supuesta democracia espacial puede causar también problemas de percepción, como descubrió Kevin Lynch a finales de los años cincuenta:

Cuando se les pedía que describieran o simbolizaran la ciudad en conjunto, los entrevistados empleaban uniformemente ciertas palabras: 'desparramada', 'espaciosa', 'informe', 'sin centros'. Parecería que es difícil representar visualmente o conceptualizar a Los Ángeles como una totalidad. La imagen general era la de una extensión interminable, lo cual puede llevar consigo agradables sugerencias de espacio en torno de las viviendas o matices de tedio y desorientación" (Lynch, 2008, p. 53).

Esta dispersión ha provocado un aumento de los paisajes intermedios en el interior de la ciudad, una serie de espacios a medio camino entre el entorno natural y el entorno humanizado que han sido descritos por Lars Lerup como "incompletos, inacabados, estancados en algún punto entre el desarrollo y el abandono" (Lerup, 2000, p. 158).3 Los principales nodos en esta clase de territorios, que no son ni urbanos ni rurales, son no-lugares como aeropuertos, autopistas, hoteles o centros comerciales, es decir, aquellos espacios que, siguiendo la definición del antropólogo francés Marc Augé, "no

\footnotetext{
${ }^{3} \mathrm{El}$ concepto de paisaje intermedio fue formulado por primera vez por el historiador estadounidense Leo Marx en su obra The Machine in the Garden: Technology and the Pastoral Ideal in America (Marx, 1964).
} 
son en sí lugares antropológicos y que (...) no integran los lugares antiguos” (Augé, 1993, p. 83). El tejido urbano que los rodea suele carecer de una identidad distintiva, ya que ha sido moldeado a partir de modelos estandarizados reproducibles en cualquier lugar del mundo. Francesc Muñoz ha denominado paisajes banales a estos espacios intercambiables, un concepto que identifica a aquellas "morfologías urbanas relativamente autistas en relación con el territorio" (Muñoz, 2010, p. 190). Este tipo de paisaje urbano sería el resultado de la reciente tematización y brandificación de las áreas centrales y periféricas de la ciudad, un proceso que intenta transformar cada ciudad en una marca competitiva dentro del mercado mundial:

[Los paisajes banales son] una clase especifica de paisaje que, a pesar de ser ofrecido a los habitantes de la ciudad, ha sido producido para servir a los intereses, requerimientos y necesidades de la economía global. Un paisaje urbano híbrido, que, por un lado, tiene un carácter local, puesto que se mantienen algunos elementos del espacio físico y social, pero, por otro lado, mantiene una apariencia que permite su consumo estandarizado por parte de públicos globales. Este es el mecanismo que hace que los resultados finales de la renovación urbana parezcan similares a pesar de tratarse de ciudades muy diferentes (Muñoz, 2010, p. 195).

En Los, Benning retrata Los Ángeles como un conjunto de lugares dispersos que suelen encajar en una u otra de estas cuatro categorías, como se puede ver en el Cuadro 1: la presencia de algunos paisajes expandidos hace referencia a la expansión voraz de la ciudad por el territorio; la abundancia de paisajes intermedios vincula esta película con las otras dos de la trilogía; los numerosos no-lugares confirman su ubicuidad en el tejido urbano actual; y la inclusión de media docena de paisajes banales indica la aparición de nuevos espacios de poder socioeconómico en West Hollywood, Bunker Hill, Orange County, el Financial District del Downtown, Koreatown e incluso Chavez Ravine. Algunas imágenes -señaladas en cursiva más abajo- pueden incluirse en dos categorías diferentes, y tan solo diez de los treinta y cinco planos de la película -menos de un tercio del metraje- no se corresponderían con ningún tipo de paisaje, dado que están dedicados mayoritariamente a actividades productivas. 
Cuadro 1: Los, planos según tipo de paisaje

\begin{tabular}{|l|c|l|}
\hline \multicolumn{1}{|c|}{ Tipo de Paisaje } & $N^{o}$ de Planos & \multicolumn{1}{c|}{ Planos } \\
\hline Paisajes Expandidos & 5 & $3,5,17,19,20$ \\
\hline Paisajes Intermedios & 9 & $1,3,12,14,23,26,31,32,35$ \\
\hline No Lugares & 9 & $4,7,10,15,19,21,24,30,34$ \\
\hline Paisajes Banales & 6 & $2,8,9,16,21,24$ \\
\hline Actividades Productivas & 8 & $6,11,13,18,25,27,28,33$ \\
\hline
\end{tabular}

NOTA: Los planos 22 y 29 no aparecen en este cuadro porque muestran respectivamente un escuadrón de policía y un cementerio.

\section{Cuadro 2: Los, planos según su ubicación geográfica}

\begin{tabular}{|c|c|c|}
\hline $\begin{array}{l}\text { Ubicación } \\
\text { Geográfica }\end{array}$ & $\begin{array}{l}N^{o} \text { de } \\
\text { Planos }\end{array}$ & Planos \\
\hline $\begin{array}{l}\text { 1. Los Angeles County } \\
\text { - Los Angeles Plains } \\
\text { - Downtown } \\
\text { - Westside } \\
\text { - Sur } \\
\text { - Santa Monica Hills } \\
\text { - Mid-City } \\
\text { - San Fernando Valley } \\
\text { - Santa Clarita Valley } \\
\text { - Long Beach } \\
\text { - Malibu }\end{array}$ & $\begin{array}{l}3 \\
2 \\
1 \\
8 \\
4 \\
3 \\
1\end{array}$ & $\begin{array}{l}\text { 7, 8, 16, 22, } 34 \\
\quad \text { West Hollywood (2), Westwood (29), } \\
\text { Santa Monica (5), LAX (10), Baldwin } \\
\quad \text { Hills (23) } \\
\text { South Central (31), Vernon (28), } \\
\text { Maywood (12) } \\
\text { Griffith Park (17), Chavez Ravine Hill (24) } \\
\text { Koreatown (21) } \\
\text { 1, 4, 11, 14, 20, 25, 27, } 30 \\
3,4,19,33 \\
6,15,18 \\
35\end{array}$ \\
\hline 2. Orange County & 3 & $9,13,26$ \\
\hline 3. Riverside County & 1 & 32 \\
\hline
\end{tabular}

NOTA: El plano 4 fue filmado en el Newhall Pass, la frontera natural entre los valles de San Fernando y Santa Clarita, por lo que ha sido contado dos veces.

La combinación de estos cuatro paisajes refleja el elevado nivel de entropía que caracteriza las ciudades del Sun Belt: cuanto menos organizado está un territorio, menos definida será su identidad, como sugirió Albert Pope en su libro Ladders (Pope, 1996). La urbanización regional masiva en el sur de California ha llevado al Gran Los Ángeles a expandirse, en concreto, por cinco condados diferentes: Los Ángeles, Orange, San Bernardino, Riverside y Ventura. Benning filmó la mayor parte de Los sin salir del primero, dado que su extensa superficie $\mathbf{- 1 0 . 5 7 0}$ kilómetros cuadrados- le permitieron documentar una amplia variedad de lugares y paisajes, como se puede ver en el Cuadro 2 y en el Mapa 1. El vértice de Benning en esta región, según los resultados del mapa, es siempre Val Verde, su lugar de residencia, situado al 
noroeste de Los Ángeles (en la esquina superior izquierda del mapa): ese es el lugar desde el que Benning percibe el territorio, ya sea el Gran Los Ángeles, el Central Valley o el estado de California en su conjunto. Desde allí, el cineasta está obligado a tomar la Interestate 5 -la autopista que vertebra buena parte de la región urbana de Los Ángeles y la comunica con las principales ciudades de la costa oeste- para llegar a cualquier destino, en un movimiento perpetuo que documenta implícitamente la dependencia del automóvil que hay en las ciudades del Sun Belt. De ahí que muchas películas de Benning puedan considerarse también como diarios de viajes o incluso road movies.

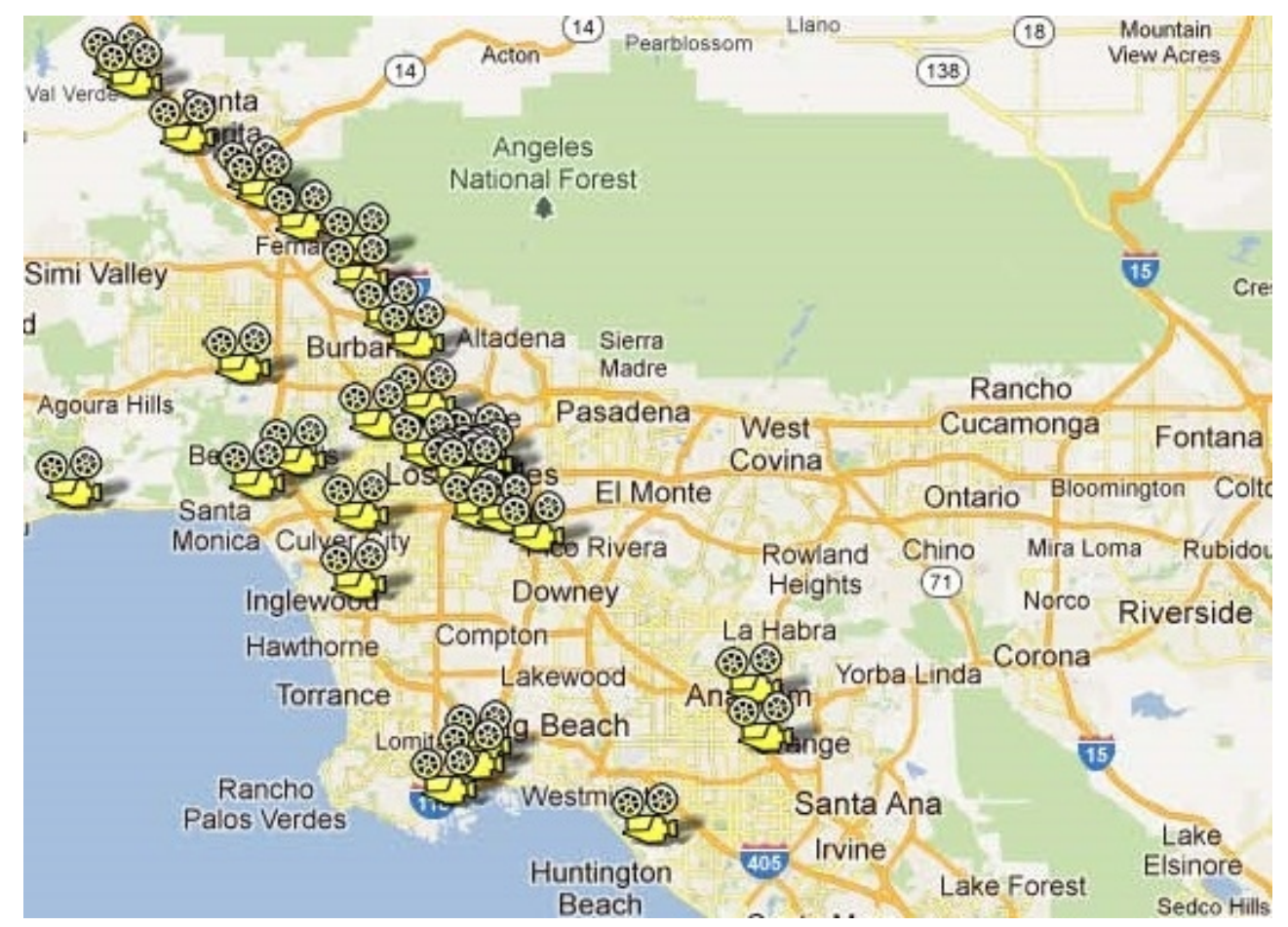

Mapa 1. Localizaciones de rodaje de Los. Mapa disponible en http://g.co/maps/ct97j

El cineasta contrarresta en Los la sobrerrepresentación en el cine mainstream de las zonas de renta más elevada al destacar la importancia demográfica y territorial de los suburbios del valle de San Fernando y del de Santa Clarita. Hay más imágenes de estas dos áreas juntas -en concreto, 11 planos en total, casi un tercio del metraje- que del conjunto del Westside y Orange County -8 planos- o el Westside y el Downtown -10 planos- en un intento explícito de equilibrar su presencia real y simbólica en la 
experiencia cotidiana de la ciudad para alguien, como Benning, que vive en sus suburbios septentrionales. Por este motivo, el Downtown aparece representado únicamente por sus dos extremos: el oeste, entre Figueroa y Olive Street, que es el territorio de los rascacielos y los hombres de negocios [planos $7^{\circ}$ y $16^{\circ}, \mathrm{F} 3$ ]; y el este, entre Main Street y el río Los Ángeles, que es en donde se encuentra la cárcel del condado y la mayor parte de indigentes de la región [planos $8^{\circ}$ y $34^{\circ}, \mathrm{F} 4$ ]. El punto de sutura entre estos dos mundos -el corredor Broadway-Spring- no aparece en la película, quizás para enfatizar la polarización espacial de la zona, que ha sido describa por Soja en los siguientes términos:
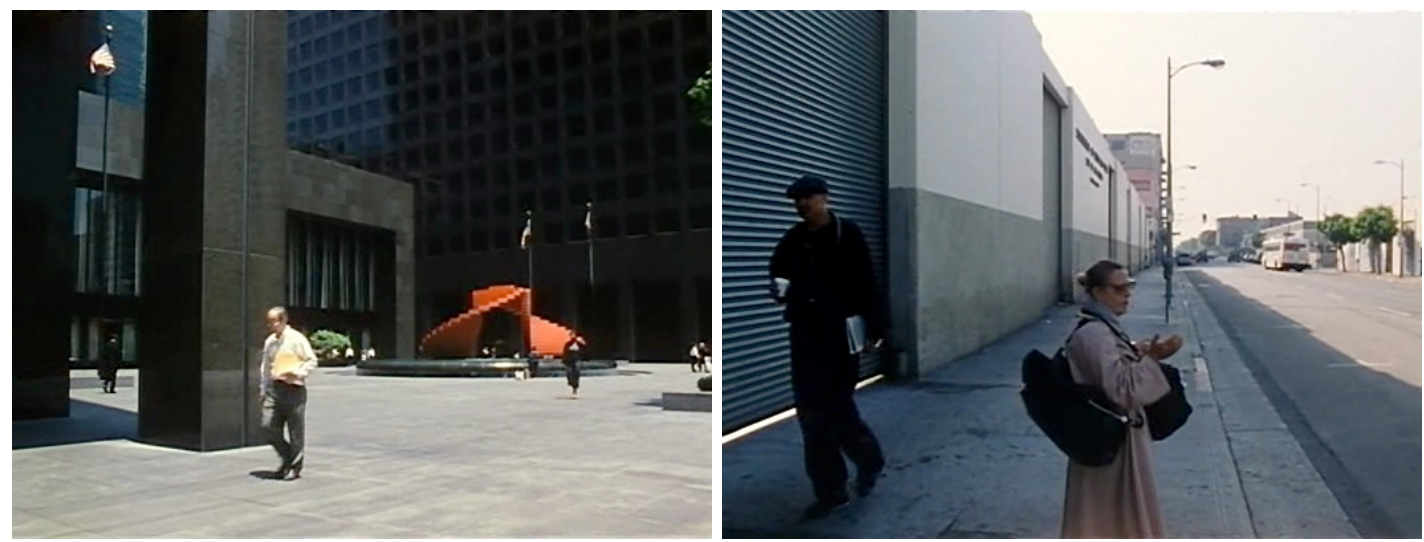

F 3 y 4: Los, Arco Plaza (izquierda) y Skid Row (derecha)

En relación con el empleo y la vivienda en particular, este enclave en el centro de la ciudad es el lugar de dos llamativas aglomeraciones que representan los extremos de presencia y ausencia. La mitad oeste, formada por el complejo administrativo de la ciudad, del condado y del estado así como las oficinas federales y las torres corporativas del Distrito Central de Negocios y su extensión al sur alrededor del centro de convenciones, es el lugar de mayor densidad de empleos de la postmetrópolis policéntrica. En medio de la lista de enclaves que comprende la mitad este, está Skid Row, en el que cualquier noche puedes encontrar la mayor concentración de personas sin hogar de la región si no de EEUU. Con cruel ironía, los indigentes, carentes de trabajo y alojamiento, pueden superen en número a los residentes legales que cuentan con un buen empleo en el Downtown, pese a los esfuerzos públicos y privados para atraer a residentes de clase media a esta zona y controlar -o directamente eliminar-Skid Row (Soja, 2008, p. 358). 
Benning evitó conscientemente la mayoría de lugares reconocibles de la ciudad dado que su principal propósito era restaurar la presencia en pantalla de la clase obrera: frente a aquellos discursos que afirmaban su desaparición como consecuencia de la crisis industrial, Los revela un paisaje urbano dominado por todo tipo de lugares de trabajo en donde los trabajadores están representados de forma metonímica. Como se puede ver en el Cuadro 3, dos tercios del metraje están dedicados a los usos productivos del territorio, entre los que destacan las actividades del sector terciario, desde el comercio internacional hasta la gestión de residuos. A su vez, ciertas actividades del sector primario, como la agricultura y la minería, todavía siguen presentes en el interior de la ciudad, mientras que la industria parece experimentar un ligero retroceso: cuatro planos de treinta y cinco no parecen demasiados, pero al menos muestran instalaciones en funcionamiento. 4 Los seis planos de infraestructuras de agua y transporte han sido contados como usos productivos del suelo al ser esenciales para la circulación de materias primas y mercancías, como la propia agua. Los usos recreativos, a su vez, se corresponden con aquellos lugares en los que la naturaleza invade la ciudad, como los parques, las playas, los cementerios o los campos de deportes, así como lugares de reunión como la Crystal Cathedral de Garden Grove, en Orange County. Por último, el uso residencial del territorio tan sólo aparece en un par de planos, que no obstante resumen perfectamente la lógica de la urbanización dispersa desde la colonización del territorio [F 5] al usufructo de la tipología residencial más deseada [F 6].

\section{Cuadro 3: Los, planos según usos del suelo y tipo de actividad económica}

\begin{tabular}{|c|c|c|}
\hline Usos del suelo & $N^{O}$ de planos & Planos por tipo de actividad \\
\hline 1. Uso Productivo & 24 & \\
\hline -Sector Primario & 3 & Agricultura (31), Minería $(23,33)$ \\
\hline -Sector & 4 & Industria $(11,18,28)$, Construcción (27) \\
\hline Secundario & 11 & Comercio $(6,15,21)$, Mercado Inmobiliario \\
\hline - Sector Terciario & & $(3,8)$, Instituciones Represivas $(7,22)$, \\
\hline - Infraestructuras & 6 & $\begin{array}{l}\text { Gestión de Residuos (13, 25), Finanzas (16), } \\
\text { Publicidad (2) }\end{array}$ \\
\hline & & Red de Transportes $(4,10,15,30)$, \\
\hline
\end{tabular}

\footnotetext{
${ }^{4}$ La desindustrialización de Los Ángeles nunca alcanzó el nivel de las ciudades del Rust Belt, dado que la ciudad también experimentó un proceso simultáneo de reindustrialización que, según Soja, “reorganizó el fordismo en direcciones muy diferentes" (Soja, 2008, p. 252).
} 


\begin{tabular}{|l|l|l|}
\hline & & \multicolumn{1}{|c|}{ Infraestructuras Hidráulicas (1, 12) } \\
\hline 2. Uso Recreativo & 9 & $\begin{array}{l}\text { Espacios Abiertos (5, 17, 26, 29, 32, 35), } \\
\text { Deportes (14, 24), Lugares de Reunión (9) }\end{array}$ \\
\hline 3. Uso Residencial & 2 & 3,20 \\
\hline
\end{tabular}

NOTA: El plano 34 no aparece en este cuadro porque muestra más bien la falta de vivienda en Skid Row
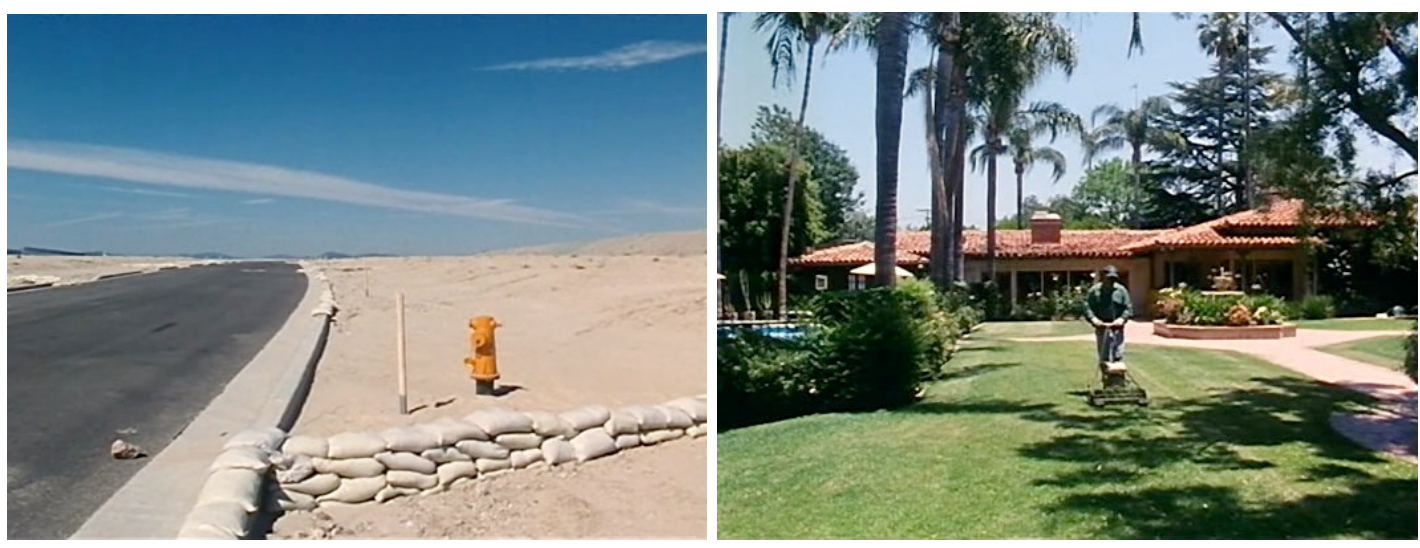

Imágenes 5 y 6: Los, parcelas urbanizables en Stevenson Ranch (izquierda) y una vivienda privada en Encino (derecha)

La imagen de las parcelas urbanizables en Stevenson Ranch documenta un paisaje en construcción que acaba de ser arrebatado a la naturaleza: es la clase de paisaje intermedio que precede a la explosión de la urbanización dispersa. Benning filmó este plano muy cerca de su casa en Val Verde, justo en el límite de la frontera urbana, en un lugar en el que un nuevo suburbio estaba a punto de ser construido. Este tipo de comunidades exteriores llevan el mito de la frontera americana al contexto postmetropolitano al consumir grandes cantidades de territorio y, en consecuencia, moldear espacios caracterizados por su profunda insostenibilidad en términos funcionales, ambientales, sociales y culturales (Muñoz, 2010, p. 172). Al mostrar el interregno entre el entorno natural y el humanizado, Benning no hace más que recordarnos que "Los Ángeles fue sobre todo la creación del capitalismo inmobiliario, la especulación culminante, de hecho, de generaciones de impulsores y promotores que había subdividido y vendido el Oeste, desde Cumberland Gap al Pacífico" (Davis, 2003, p. 8).

Los lugares retratados en Los son en realidad piezas de una narrativa histórica que explica el crecimiento sostenido de Los Ángeles desde principios del siglo 
XX. Comenzando con el capitalismo inmobiliario [planos 3, 8 y 20], el desarrollo de la ciudad sólo pudo ser posible gracias a la construcción de una amplia red de infraestructuras hidráulicas [planos 1 y 12 ] y varias redes de transporte regional [planos 4 y 30]. La economía local se benefició de la creación de una bahía artificial en 1907 [plano 6], del establecimiento de la industria cinematográfica en los años diez [plano 2], del descubrimiento de nuevos campos de petróleo en los años veinte [planos 18 y 23], del auge de la industria aeronáutica tras la Segunda Guerra Mundial [plano 10] y de la reciente integración de la ciudad en las redes del capital global [planos 8, 16 y 21]. Este relato de un progreso económico continuado también oculta una contrahistoria llena de escándalos políticos, protestas sociales y revueltas violentas, en las que el recurso a las instituciones represivas ha sido la forma habitual de mantener la paz social [planos 7 y 22].

Todos estos lugares y actividades se representan en Los con una profunda conciencia de clase, sugiriendo en consecuencia que el espacio social en Los Ángeles ha sido históricamente producido a partir de criterios de clase, raza y género (James, 2005, p. 427). La película es bastante clara en este punto: los espacios del poder -el Westside, Orange County, el Financial District del Downtown y el Valle de San Fernando- son territorios blancos [planos 5, 9, 16 y 20], pero la mayoría de personas que aparece en el metraje son en realidad latinos, como ya ocurría en El Valley Centro [planos 7, 14, 17, 19, 20 y 31]. Además, la elección de ciertas localizaciones evoca indirectamente una historia concreta de clase y de raza, como en el caso de Bunker Hill [plano 8, F 7] y Chavez Ravine [plano 24], dos antiguos barrios de clase obrera -el segundo habitado principalmente por chicanos- que fueron erradicados de la trama urbana en los años cincuenta para dar paso, respectivamente, al Financial District y al Dodgers Stadium. Benning nunca explicita estos relatos históricos porque suele estar más interesado en el presente que en el pasado del territorio, pero esto no significa que no sea consciente del valor conmemorativo de sus imágenes. Al contrario, si él filma el presente es precisamente para documentar todo aquello que podría desaparecer en un 
futuro, como el South Central Community Garden [plano 31, F 8], que actualmente no es más que una parcela vacía de terreno. 5
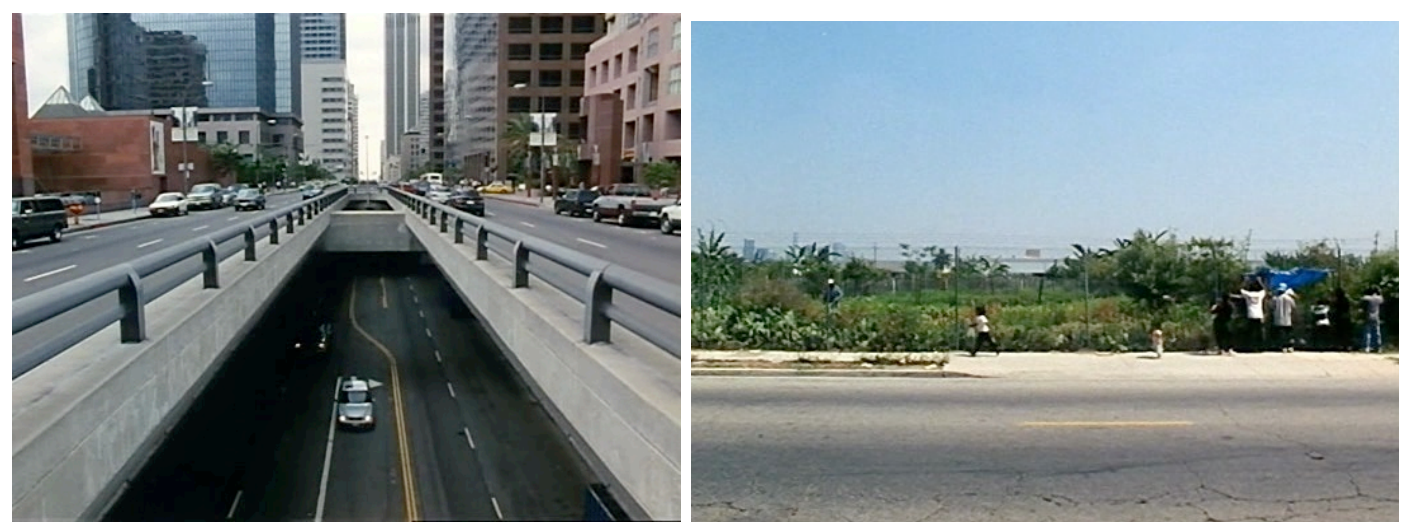

F 7 y 8: Los, Bunker Hill (izquierda) y South Central Community Garden (derecha)

\section{Conclusión: De lo Observacional a lo Performativo}

Dentro de cada uno de los treinta y cinco planos de Los, Benning establece una serie de tensiones internas y micronarrativas para enfatizar su condición de paisajes en movimiento. El efecto resultante puede ser la hipnosis inducida por secuencias cíclicas o flujos continuos, la sorpresa ante acontecimientos inesperados o la incerteza de no saber si una acción se va a completar dentro de la duración del plano. Durante dos minutos y medio, el público puede explorar el paisaje con sus ojos en lugar de con sus pies, como si estuviese en ese mismo lugar junto al propio Benning. Por consiguiente, lo que se suponía que era un registro objetivo del paisaje urbano se convierte en realidad en un viaje subjetivo que vincula el paisajismo observacional con el autobiográfico: los treinta y cinco planos de Los son en realidad treinta y cinco performances en las que el cineasta visita distintos lugares del Gran Los Ángeles para filmar "como [se] siente en esos lugares en esos precisos momentos" (Benning en MacDonald, 2006, p. 245). Desde esta perspectiva, cada localización de rodaje en el conjunto de la trilogía es, ante todo, un espacio vivido que Benning desea compartir con el público:

\footnotetext{
${ }^{5}$ Un grupo de residentes latinos del barrio de South Central convirtieron este lugar en una granja urbana desde 1994 hasta 2006, cuando fue destruida a petición de su propietario nominal. La película The Garden (Scott Hamilton Kennedy, 2008) documenta la lucha de estos granjeros urbanos por conservar el uso agrícola de este terreno.
} 
Yo tiendo cada vez más a experimentar cosas por mí mismo y a realizar películas sobre esas experiencias porque creo que hay algo maravilloso en compartirlas con alguien. Pero si alguien me acompañase durante el rodaje de estas películas, simplemente no podría hacerlas. Tengo que tener esa experiencia por mí cuenta para poder filmarla (Benning en Ault, 2007, p. 90).

Siendo tan observacional como performativa, la Trilogía de California muestra así un paisaje que es simultáneamente objetivo y subjetivo, material y emocional, épico y lírico: podemos entenderlo como un conjunto de "capas sedimentadas de acontecimientos históricos" (Slanar, 2007, p. 178), "un mapa de denuncia política” (Muñoz Fernández, 2011) o una proyección geográfica del propio cineasta. Esto quiere decir que incluso un dispositivo cinematográfico tan neutro y distanciado como el paisajismo puede transmitir una visión personal del espacio representado, en la medida en que la forma en la que alguien mira el paisaje revela implícitamente una forma de estar en el mundo y de relacionarse con él. Por lo tanto, la Trilogía de California de James Benning puede considerarse como una cartografía cinematográfica de las transformaciones en curso de este territorio, así como un diario privado de los viajes y experiencias del cineasta a través de su geografía, siempre según qué película quiera el público ver.

\section{Apéndice: Lista de localizaciones de rodaje de Los}

Plano 1. Cascada, Acueducto de Los Ángeles, Sylmar

Plano 2. Anuncio, Outdoor Systems, Inc., West Hollywood

Plano 3. Parcelas urbanizables, Newhall Land \& Farming Co., Stevenson Ranch

Plano 4. Lluvia de verano, Golden State Freeway, Newhall Pass

Plano 5. Corredores, San Vicente Boulevard, Santa Mónica

Plano 6. Buque de carga, Matson Navigation Co., San Pedro

Plano 7. Cárcel central masculina, Condado de Los Ángeles, Los Ángeles

Plano 8. Calle a dos niveles, Grand Avenue, Los Ángeles 
Plano 9. Crystal Cathedral, Robert H. Schuller Ministries, Garden Grove

Plano 10. Aviones aterrizando, Aeropuerto Internacional de Los Ángeles, Los Ángeles

Plano 11. Fábrica, City of Burbank, Burbank

Plano 12. Río Los Ángeles, Flood Control District, Maywood

Plano 13. Desguace, PYP Auto Wrecking, Anaheim

Plano 14. Fútbol, Hansen Dam Park, Pacoima

Plano 15. Intersección, Henry Ford Avenue, Terminal Island

Plano 16. Gente de negocios, Arco Plaza, Los Ángeles

Plano 17. Los Ángeles skyline, Griffith Observatory, Los Feliz

Plano 18. Refinería de petróleo, Ultramar Corporation, Wilmington

Plano 19. Parada de bus escolar, San Martínez Road, Val Verde

Plano 20. Jardinero, Parriot Residence, Encino

Plano 21. Mini-Mall, Koreatown

Plano 22. Policía, Convención Nacional Demócrata, Los Ángeles

Plano 23. Pozo de petróleo, Stocker Resources, Inc., Baldwin Hills

Plano 24. Cuidadores del campo, Dodger Stadium, Chávez Ravine

Plano 25. Planta de eliminación de residuos, Crown Disposal, Inc., Sunland

Plano 26. Humedales, Department of Fish \& Games, Bolsa Chica

Plano 27. Trabajadores de la construcción, M. A. Mortenson Co., Inc., Los Ángeles

Plano 28. Ganado, Shamrock Meats, Inc., Vernon

Plano 29. Monumentos funerarios, National Cementery, Westwood

Plano 30. Tren de cercanías, Metrolink, San Fernando

Plano 31. Jardín comunitario, 41st Street, Los Ángeles

Plano 32. Incendio forestal, Pechanga Indian Reservation, Temecula 
Plano 33. Excavadoras, C. A. Rasmussen, Inc., Castaic Junction

Plano 34. Personas sin hogar, 6th Street, Los Ángeles

Plano 35. Océano Pacífico, Puerco Beach, Malibu

\section{Referencias bibliográficas}

AlSayyad, N. (2006). Cinematic Urbanism. A History of the Modern from Reel to Real. Nueva York, EUA, y Londres, RU: Routledge.

Althabe, G. \& Comolli, J-L. (1994). Regards sur la ville. París: Centre Georges Pompidou.

Augé, M. (1993). Los 'no lugares'. Espacios del anonimato. Una antropología de la sobremodernidad. Barcelona: Editorial Gedisa.

Ault, J. (2007). Using the Earth as Map of Himself. En B. Pichler \& C. Slanar (Eds.), James Benning (pp. 88-112). Viena: Osterreichisches Filmmuseum.

Banham, R. (1971). Los Angeles. The Architecture of Four Ecologies. Berkeley, EUA, Los Angeles, EUA y Londres, RU: University of California Press.

Barber, S. (2002). Projected Cities: Cinema and Urban Space. Londres: Reaktion Books.

Barrios, G. (1997). Ciudades de película. Caracas: Eventus.

Bradshaw, N. (2013). James Benning. Sight \& Sound, 23 (10), 46-50.

Brunsdon, C. (2010). Towards a History of Empty Spaces. En Koeck, R. \& Roberts, L. (Eds.), The City and the Moving Image: Urban Projections (pp. 91-103). Nueva York, EUA: Palgrave.

Burch, N. (1990). Life to Those Shadows. Berkeley, EUA: University of California Press.

Castro, T. (2010). Mapping the City through Film: From 'Topophilia' to Urban Mapscapes. En Koeck, R. \& Roberts, L. (Eds.), The City and the Moving Image: Urban Projections (pp. 144-155). Nueva York, EUA: Palgrave.

Clarke, D. B. (Ed.) (1997). The Cinematic City. Londres, RU, \& Nueva York, EUA: Routledge.

Davis, M. (2003). Ciudad de cuarzo. Arqueología del futuro en Los Ángeles. Madrid: Lengua de Trapo.

Davis, M. (2007). Ciudades muertas. Ecología, catástrofe y revuelta. Madrid: Traficantes de Sueños.

Dimendberg, E. (2004). Film Noir and the Spaces of Modernity. Cambridge, EUA: Harvard University Press.

Everett, W. \& Goodbody, A. (Eds.) (2005). Revisiting Space. Space and Place in European Cinema. Berna: Peter Land AG.

Font, D. (2002). Paisajes de la Modernidad. Cine europeo 196o-1980. Barcelona: Ediciones Paidós.

Harper, G. \& Rayner, J. R. (Eds.) (2010). Cinema and Landscape. Bristol, 
RU, \& Chicago, EUA: Intellect Books \& The University of Chicago Press.

Ingersoll, R. (2006). Sprawltown. Nueva York, EUA: Princeton Architectural Press.

James, D. E. (2005). The Most Typical Avant-garde: History and Geography of Minor Cinemas in Los Angeles. Berkeley \& Los Angeles, EUA: University of California Press.

Jousse, T. \& Paquot, T. (Dir.) (2005). La ville au cinema. Encyclopédie. París: Cahiers du Cinéma.

Koeck, R. \& Roberts, L. (Eds.) (2010). The City and the Moving Image: Urban Projections. Nueva York, EUA: Palgrave.

Krause, L. \& Petro, P. (Eds.) (2003). Global Cities: Cinema, Architecture, and Urbanism in a Digital Age. New Brunswick, EUA, \& Londres, RU: Rutgers University Press.

Lefebvre, H. (1974). La Production de l'espace. París: Anthropos.

Lerup, L. (2000). After the City. Cambridge, EUA: MIT Press.

Lynch, K. (2008). La imagen de la ciudad. Barcelona: Gustavo Gili.

MacDonald, S. (2006). A Critical Cinema 5. Interviews with Independent Filmmakers. Berkeley, EUA, Los Angeles, EUA, y Oxford, RU: University of California Press.

Martin, A. (2010). La tentación documental. En A. Weinrichter (Ed.), .Doc. El Documentalismo en el Siglo XXI (pp. 185-201). Donostia-San Sebastián: Festival Internacional de Cine de Donostia-San Sebastián / Filmoteca Vasca.

Marx, L. (1964). The Machine in the Garden: Technology and the Pastoral Ideal in America. Nueva York, EUA: Oxford University Press.

Mazierska, E. \& Rascaroli, L. (2003). From Moscow to Madrid. Postmodern Cities, European Cinema. Londres, RU, \& Nueva York, EUA: I.B. Tauris.

McArthur, C. (1997). Chinese Boxes and Russian Dolls: Tracking the Elusive Cinematic City. En Clarke, D. B. (Ed.), The Cinematic City (pp. 19-45). Londres, RU, \& Nueva York, EUA: Routledge.

Mennel, B. (2008). Cities and Cinema. Londres, RU, \& Nueva York, EUA: Routledge.

Muñoz, F. (2010). Urbanalización, Paisajes comunes, lugares globales. Barcelona: Editorial Gustavo Gili.

Muñoz Fernández, H. (2011). Eses mestres que nos gustaría ter. Pedagoxía da imaxe: Straub-Huillet / Benning / Godard. A Cuarta Parede, 7, 10 de diciembre de 2011. Consultado el 16 de octubre de 2013: http://www.acuartaparede.com/pedagoxia-straub-huillet-benninggodard/

Muñoz Fernández, H. (2013). Sobre a obra paisaxística de Lois Patiño. $A$ Cuarta Parede, 17, 18 de septiembre de 2013. Consultado el 24 de octubre de 2013: http://www.acuartaparede.com/obra-paisaxisticalois-patino/

Niney, F. (Dir.) (1994). Visions urbaines: villes d'Europe a l'ecran. París, 
Francia: Centre Georges Pompidou.

Oroz, E. \& Abruñeiras, I. G. (2010). Políticas de la realidad. Reconfiguración del espacio público y del territorio histórico a través del documental norteamericano contemporáneo. En A. Weinrichter (Ed.), .Doc. El Documentalismo en el Siglo XXI (pp. 101-123). Donostia-San Sebastián: Festival Internacional de Cine de Donostia-San Sebastián / Filmoteca Vasca.

Pope, A. (1996). Ladders. Houston \& Nueva York, EUA: Princenton Architectural Press.

Plath, N. (2007). On Future Arrivals of Container Drivers. Five Brief Comments on One Image from James Benning's California Trilogy, expanded. En B. Pichler \& C. Slanar (Eds.), James Benning (pp. 193209). Viena: Osterreichisches Filmmuseum.

Rodríguez Ortega, V. (2012). La ciudad global en el cine contemporáneo. Una perspectiva transnacional. Santander: Shangrila Textos Aparte.

Romney, J. (2010). In Search of Lost Time. Sight \& Sound, 20 (2), 43-44.

Shiel, M. \& Fitzmaurice, T. (Eds.) (2001). Cinema and the City: Film and Urban Societies in Global Context. Oxford, RU: Basil Blackwell Publishers.

Shiel, M. \& Fitzmaurice, T. (Eds.) (2003). Screening the City. Londres, RU: Verso.

Sitney, P. A. (2000). Structural Film. En P. A. Sitney (Ed.), The Film Culture Reader (pp. 326-348). Nueva York, EUA: Cooper Square Press.

Slanar, C. (2007). Landscape, History and Romantic Allusions. El Valley Centro (1999) to RR (2007). En B. Pichler \& C. Slanar (Eds.), James Benning (pp. 169-180). Viena: Osterreichisches Filmmuseum.

Soja, E. (2008). Postmetrópolis. Estudios críticos sobre las ciudades y las regiones. Madrid: Traficantes de Sueños.

Webber, A. \& Wilson, E. (Eds.) (2008). Cities in Transition. The Moving Image and the Modern Metropolis. Londres, RU, \& Nueva York, EUA: Wallflower Press.

Weinrichter, A. (2007). Festivales, museos y otras orillas del audiovisual. Notas sobre el estado de salud del documental y la ficción. En D. Font \& C. Losilla (Eds.), Derivas del cine europeo contemporáneo (pp. 6979). Valencia: Institut Valencia de Cinematografia Ricardo Muñoz Suay, Centro Galego de Artes de Imaxe, Filmoteca de Catalunya, Mostra Internacional de Cinema Europeu Contemporani (MICEC'o7).

Yáñez Murillo, M. (2009). Mirar y escuchar. Entrevista James Benning. Cahiers du Cinéma. España, 22, 80-81.

Cómo citar: Villarmea Álvarez, I. (2014). "El paisajismo observacional de James Benning: la representación de Los Angeles en Los (2000)”. Fotocinema. Revista científica de cine y fotografía, 9, pp. 35-64. Disponible: http://www.revistafotocinema.com/index.php?journal=fotocinema 